\title{
Monitoring of Intestinal Nematodoses of Dogs in the Kabardino-Balkarian Republic and the Test Results of the New Drug Avertfen Powder
}

\author{
Anatoly Murashevich Bittirov*1, Marina M Khulamkhanova1, Nazifat M Mirzoeva ${ }^{1}$, Safiyat M Balaeva ${ }^{2}$ and Asiyat A \\ Bittirova $^{1}$
}

${ }^{1}$ Department of Veterinary Medicine, Russia

${ }^{2}$ Department of General Biology, Biodiversity and Geoecology, Russia

Received: 眥 January 04, 2019; Published: 眥 January 24, 2019

*Corresponding author: Anatoly Murashevich Bittirov, Department of Veterinary Medicine, Nalchik, Russia

\begin{abstract}
In the constituent entities of the Russian Federation, the most common nematodes are toxocarosis, ankylostomosis, uncinariosis, toxoascariosis, which occur in dogs with an EI of 50-100\%. The goal is to monitor intestinal nematodes in dogs in Kabardino-Balkaria and to test the effectiveness of the new drug Avertfen powder in mixed invasion of intestinal nematodes in dogs. Studies have shown that intestinal nematodoses of dogs in the form of mono and mixed invasions are widespread in the Kabardino-Balkarian Republic with a total EI of 78.6\%. Associative invasion caused by a tetrade of intestinal nematodes (Toxocara canis, Ancylostoma caninum. Toxascaris leoninae, Uncinaria stenocephala) was observed mainly with EI = $38,0 \%$ with an intensity of $169.7 ; 132.5 ; 94.8 ; 147,3 \mathrm{ekz}$. /head. In the group of dogs infected with the mixed invasion Toxocara canis, Ancylostoma caninum., Toxascaris leoninae, Uncinaria stenocephala, the new drug Avertfen powder in a dose of $15 \mathrm{mg} / \mathrm{kg}$ body weight had EE and IE - $100 \%$. At the same time, on the 7th day, deworming of eggs and larvae of intestinal nematodes was not detected in feces. This dose of Avertfen powder should be recognized as an effective therapeutic dose.
\end{abstract}

Keywords: Dogs; Invasia; Nematodoses; Drug; Avertfen Powder; Extensefficiency

\section{Introduction}

In the subjects of the Russian Federation, toxocarosis, ankylostomosis, uncinariosis, toxoascariosis, etc. are the most common nematodoses and occur in dogs with an EI of 70-100\%, which requires the development of new drugs for the treatment and prevention of invasions [1-15]. In young dog populations, nematodoses (toxocarosis, ankylostomosis, uncinariosis, toxoascariosis) have an epizootic manifestation with the formation of mixed invasions [115] The goal is to study the nosological profile of nematodoses in dogs in the Kabardino alkarian Republic and to test the effectiveness of the new drug Avertfen powder in mixed invasion of intestinal nematodoses in dogs (toxocarosis, ankylostomosis, uncinariosis and toxoascariosis).

\section{Materials and Methods}

The spread of mono- and associative invasions of intestinal nematodoses of dogs in the Kabardino-Balkarian Republic was determined in 2015-2018. For this, a complete helminthological autopsy of 50 corpses of dogs aged 5-12months was carried out according to the method of K.I.Scriabin. An experiment to test the anthelmintic activity of the drug Avertfen powder with mixed invasion of intestinal nematodes (Toxocara canis, Ancylostoma caninum., Toxascaris leoninae, Uncinaria stenocephala) was conducted on 15 dogs. 2 experimental $(n=10)$ and 1 control $(n=5)$ groups of dogs were formed. Dogs of the $1^{\text {st }}$ group $(n=5)$ infected with mixed invasion of intestinal nematodes received a new drug Avertfen powder at a dose of $10 \mathrm{mg} / \mathrm{kg}$ of body weight with minced meat, dogs of the $2^{\text {nd }}$ group $(n=5)$ at a dose of $15 \mathrm{mg} / \mathrm{kg}$ body weight, once. The dogs of the $3^{\text {rd }}$ group $(n=5)$ served as an invasive control, they did not receive a new drug. According to the plan of the experiment, after $3,5,7,10$ and 15 days after a single injection of the drug Avertfen of the excrement of all dogs were subjected to copro and lasroscopy [6]. The test results on dogs of the new drug Avertfen of the powder with associative invasion of nematodes $(T$. canis, A. caninum., T. leoninae, U. stenocephala) were subjected to statistical processing using the program «Biometrics». 


\section{Results}

\section{Distribution of Mono and Mixed Invasions of Intestinal Nematodoses of Dogs in the Kabardino-Balkarian Republic}

Research found that intestinal nematodoses dog (Toxocarosis, Ankylostomosis, Toxoascariosis, Uncinariosis) in the form of mono and mixed invasions are widespread in the KabardinoBalkarian Republic with a total EI of 88,0\% (Table 1). Monoinvasion of toxocarosis, in dogs was registered with $\mathrm{EI}=16.0 \%$ and II $=169.7 \pm 13$,2ekz., ankylostomosis, respectively, with EI-12, 0\% and II-132.5 \pm 10 , 4ekz., toxoascariosis EI-8,0\% and II-94.8 \pm 7 , 9ekz., uncinariosis EI-14,0\% and II-147,3 \pm 12 ,8ekz. per 1 head. At autopsy in dogs of the small intestine, the highest quantitative values of EI were for mixed invasions of the intestinal nematodes, but with low values of intensity, which confirms the hypothesis of interspecific competition between childbirth Toxocara, Ancylostoma, Toxascaris, Uncinaria. Associative invasion caused by the intestinal nematodes (Toxocara canis, Ancylostoma caninum, Toxascaris leoninae, Uncinaria stenocephala) was observed mainly with $\mathrm{EI}=38,0 \%$ with an intensity of $136,4 \pm 11,0 ; 102,7 \pm 9,5 ; 73,6 \pm 6,8 ; 112,8 \pm 10,3$ ekz. / head (Table 1).

Table 1: Distribution of mono-and mixed invasions of intestinal nematodoses of dogs in the Kabardino-Balkarian Republic, $\mathrm{n}=50$.

\begin{tabular}{|c|c|c|c|c|c|}
\hline № & Nematodoses dogs & Researcher dogs & Invazed dogs & EI, $\%$ & II, ekz. $/$ ind. \\
\hline 1 & Toxocarosis & - & 8 & 16,0 & $169.7 \pm 13,2$ \\
\hline 2 & Ankylostomosis & - & 6 & 12,0 & $132.5 \pm 10,4$ \\
\hline 3 & Toxoascariosis & - & 4 & 8,0 & $94.8 \pm 7,9$ \\
\hline 4 & Uncinariosis & - & 19 & 14,0 & $147,3 \pm 12,8$ \\
\hline 5 & $\begin{array}{c}\text { Toxocarosis+ Ankylostomosis+ } \\
\text { Toxoascariosis+ Uncinariosis }\end{array}$ & - & & 38,0 & $136,4 \pm 11,0$ \\
\hline 6 & Total investigated dogs & 50 & 44 & 88,0 & $112,8 \pm 10,3$ \\
\hline
\end{tabular}

Efficacy of the New Drug Avertfen Powder with Associative Invasions Toxocarosis, Ankylostomosis, Uncinariosis, Toxoascariosis in Dogs

The new complex drug Avertfen powder per $1 \mathrm{~g}$ of powder includes: Avertin powder 50\%-350mg, fenbendazole - 250mg, cobalt chloride- $50 \mathrm{mg}$, dry bentonite- $350 \mathrm{mg}$. In the $1^{\text {st }}$ experimental group of dogs $(n=5)$ infected with mixed invasion of intestinal nematodes (Toxocara canis, Ancylostoma caninum., Toxascaris leoninae, Uncinaria stenocephala) mixed with minced meat, the new drug Avertfen powder at a dose of $10 \mathrm{mg} / \mathrm{kg}$ body weight showed EE - 80, $0 \%$ and IE - 93, $0 \%$ (Table 2). In the $2^{\text {nd }}$ group of dogs $(n=5)$ infected with the mixed invasion of T. canis, A. caninum, T. leoninae,

Table 2: Efficacy of the new drug Avertfen powder with associative invasions of intestinal nematodes (T. canis, A. caninum, T. leoninae, U. stenocephala) in dogs.

\begin{tabular}{|c|c|c|c|c|c|c|}
\hline \multirow{2}{*}{ Group } & \multirow{2}{*}{$\begin{array}{c}\text { The number of } \\
\text { infected dogs }\end{array}$} & $\begin{array}{c}\text { The number of free from } \\
\text { intestinal nematodes of dogs after } \\
\text { treatment }\end{array}$ & \multirow{2}{*}{ EE, \% } & \multicolumn{2}{|c|}{$\begin{array}{c}\text { Number of eggs and larvae of intestinal nematodes y } \\
\text { dogs per 5 g feces, ekz. }\end{array}$} & After therapy \\
\cline { 3 - 6 } & 5 & 4 & 80,0 & $97,3 \pm 8,6$ & $6,8 \pm 0,7$ \\
\hline 1 & 5 & 5 & 100 & $95,6 \pm 8,4$ & - & 93,0 \\
\hline 3 & 5 & 0 & 0 & $94,8 \pm 8,2$ & $96,5 \pm 8,5$ \\
\hline
\end{tabular}

\section{Discussion}

For the first time, the results of studying the distribution of intestinal nematodoses of dogs (toxocarosis, ankylostomosis, uncinariosis, toxoascariosis) in the form of mono and mixed invasion, as well as the effectiveness of the new drug Avertfen in powder against intestinal nematodis of dogs. New data were also obtained on the epizootology of toxocarosis, ankylostomosis, uncinariosis, toxoascariosis in dogs, and the therapeutic efficacy of Avertfen powder at a dose of $15 \mathrm{mg} / \mathrm{kg}$ of body weight with
U. stenocephala, the new drug Avertfen powder at a dose of $15 \mathrm{mg} /$ $\mathrm{kg}$ body weight had EE and IE-100\%. At the same time, on the $5^{\text {th }}$ day the deworming of eggs and larvae intestinal nematodes in feces did not detect (Table 2). This dosage of Avertfen powder should be recognized as an effective therapeutic dose (Table 2). Group 3 dogs (invasive control, $\mathrm{n}=5$ ) remained infected with intestinal nematodes when detecting 94,8 $\pm 8,2-96,5 \pm 8,5$ ekz. eggs and larvae in $5 \mathrm{~g}$ feces. Thus, the new complex drug Avertfen powder a dose of $15 \mathrm{mg} /$ $\mathrm{kg}$ of body weight, mixed with minced meat, is highly effective in experiments and is recommended for the treatment and prevention of associative invasions of intestinal nematodes Toxocara canis, Ancylostoma caninum, Toxascaris leoninae, Uncinaria stenocephala in dogs. mixed invasion. At the same time, information on the species composition of nematodes and the need to develop new methods for the treatment and prevention of mixed invasions of toxocarosis, ankylostomosis, uncinariosis, toxoascariosis in dogs is consistent with the opinion of many well-known authors [1-15].

\section{Conclusion}

Research found that Toxocarosis, Ankylostomosis, Toxoascariosis, Uncinariosis in the form of mono and mixed invasions are 
widespread in the Kabardino-Balkarian Republic with a total EI of $88.0 \%$. Associative invasion caused by the intestinal intestinal nematodes (Toxocara canis, Ancylostoma caninum, Toxascaris leoninae, Uncinaria stenocephala) was observed mainly with EI=38.0\% with an intensity of $136,4 \pm 11,0 ; 102,7 \pm 9,5 ; 73,6 \pm 6,8 ; 112,8 \pm 10,3 \mathrm{ekz}$./ head. New complex drug Avertfen powder at a dose of $15 \mathrm{mg} /$ $\mathrm{kg}$ of body weight, mixed with minced meat, is highly effective in experiments and is recommended for the treatment and prevention of associative invasions of nematodes in the organizme dogs.

\section{References}

1. Kabardiev S Sh, Bittirov AM, Gazimagomedov MG, Magomedov OA, Begiev S Zh, et al. Complex antiparasitic composition «Azinal plus»-3 for chemotherapy and prevention of trichuriasis, ankilostomosis and echinococcosis of dogs.

2. Zalikhanov M Ch, Bittirov AM, Begiev SA (2018) Modern biological threats and global regulation to ensure the biosafety of livestock products. In the collection: Breeding on modern populations of domestic dairy cattle as the basis for the import substitution of livestock products. Materials of the All-Russian scientific-practical conference with international participation. FSBI Belgorod Federal Agricultural Research Center of the Russian Academy of Sciences pp. 245-253.

3. Bittirov AM, Kabardiev SSh, Gazimagomedov MG, Magomedov OA, Abdulmagomedov SSh, et al. (2017) Ecological and epizootic assessment of the fauna of bio- and geohelminths of sheep in the climatic zones of the North Caucasus. Veterinary Medicine 9: 36-39.

4. Bittirov AM, Shakhbiev Kh Kh (2013) The results of epizootological studies and measures to combat the dominant helminthiases of animals in the region of the North Caucasus. In the collection: Scientific support for the sustainable development of the agro-industrial complex in the North Caucasian Federal District. Collection of reports of the All-Russian scientific-practical conference with international participation pp. 592595.

5. Kabardiev S Sh, Bittirov AM, Begieva SA, Bittirova AA, Magomedov OA, et al. A new anthelmintic drug for the treatment and prevention of osterohagiosis in cattle and small ruminants. patent for the invention RUS 260813226.

6. Shakhbiev Kh Kh, Shakhbiev I Kh, Bittirov AM (2016) Preparations «Triclafenal» and «FascoVerm plus» in the treatment of fasciolesis in the North Caucasus and imported breeds of ruminants. In the collection:
Science and Youth. All-Russian scientific and practical conf. students, young scientists and graduate students p. 90-94.

7. Bittirov AM, Kabardiev S Sh, Gazimagomedov MG, Magomedov OA, Begiev S Zh, et al. (2014) Integrated method of treatment of cattle fasciolesis. patent for invention RUS 2584212.

8. Shikhalieva MA, Atabieva Zh A, Kolodiy IV, Bittirov AM, Sarbasheva MM, et al. (2012) The structure of the parasitocenosis of the North Caucasus. Veterinary Pathology 2(40): 109-113.

9. Bittirov AM, Kabardiev S Sh, Begiev SA, Karpuschenko KA, Bittirova AA, et al. (2016) Anthelmintic agent for the treatment and prevention of fasciolesis, dicroceliosis and paramptomatosis of cattle and small ruminants. patent for the invention RUS 2612013.

10. Bittirov AM, Kabardiev S Sh (2014) Veterinary and sanitary problems of regional pathology of fasciolesis of sheep and goats in the region of the North Caucasus and new methods for their elimination. Scientificpractical publication. Makhachkala

11. Uspensky AV, Kabardiev S Sh, Bittirov AM (2014) Problems of regional pathology and prevention of dangerous zoonoses in the region of the Central Caucasus. In the collection: Materials of scientific works of the Doctor of biological sciences, Prof. Bittirov AM «Theory and practice of innovative development of agrarian science». Dedicated to the $55^{\text {th }}$ birthday. Caspian Zonal Vete. Research Institute. Makhachkala, pp. 310314.

12. Bittirov AM, Kabardiev S Sh, Magomedov OA, Musaev ZG, Eldarova $\mathrm{L} \mathrm{Kh}$, et al. (2015) The effectiveness of new compositions based on albendazole and fenbendazol in intestinal sheep nematodoses. Theory and practice of combating parasitic diseases 16: 57-58.

13. Bittirov AM, Begiev SZh, Bittirova AA, Kabardiev SSh, Eldarova L Kh, et al. (2015) Embryotropic properties of the new composition of fenbendazole and albendazole (panaverm plus). Russian parasitological journal 3: 86-88.

14. Thakakhova AA, Bittirova AA, Berezhko VK, Bittirov AM (2017) The species composition of helminthes and the contamination of sheep in the mountain tracts of Kabardino-Balkaria at an altitude of 1200-2500 $\mathrm{m}$. Sea. Theory and practice of combating parasitic diseases. 18: 492495.

15. Bittirov AM, Kabardiev SSh, Begiev S Zh, Bittirova AA, Shakhbiev Kh Kh (2016) New complex treatment of chronic fasciolesis of domestic goats. Proceedings of the All-Russian correspondence scientific-practical conference pp. 111-116.

\section{ISSN: 2574-1241}

DOI: 10.26717/BJSTR.2019.13.002419

Anatoly Murashevich Bittirov. Biomed J Sci \& Tech Res

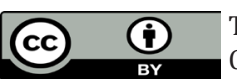

This work is licensed under Creative Commons Attribution 4.0 License

Submission Link: https://biomedres.us/submit-manuscript.php

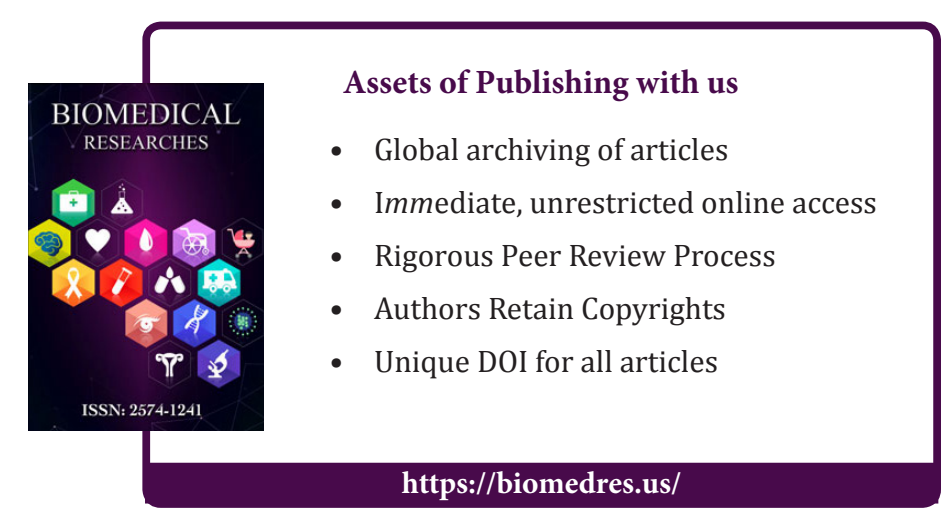

